\title{
The Amine Functionalized Sugarcane Bagasse Biocomposites as Magnetically Adsorbent for Contaminants Removal in Aqueous Solution
}

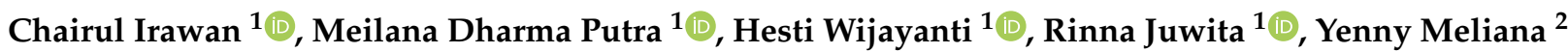 \\ and Iryanti Fatyasari Nata $1,3, *$ (D)
}

1 Department of Chemical Engineering, Lambung Mangkurat University, Banjarbaru 70714, Indonesia; cirawan@ulm.ac.id (C.I.); mdputra@ulm.ac.id (M.D.P.); hesti.wijayanti@ulm.ac.id (H.W.); rinna.juwita@ulm.ac.id (R.J.)

2 Indonesian Institute of Science, Research Centre Chemistry, Tangerang 15314, Indonesia; yenn001@lipi.go.id 3 Wetland-based Materials Research Centre, Research Institute and Community Service, Lambung Mangkurat University, Banjarbaru 70714, Indonesia

* Correspondence: ifnata@ulm.ac.id

\section{check for}

updates

Citation: Irawan, C.; Putra, M.D.; Wijayanti, H.; Juwita, R.; Meliana, Y.; Nata, I.F. The Amine Functionalized Sugarcane Bagasse Biocomposites as Magnetically Adsorbent for Contaminants Removal in Aqueous Solution. Molecules 2021, 26, 5867 https://doi.org/10.3390/ molecules26195867

Academic Editors: Artem Kozlovskiy, Uglov Vladimir and Kanyukov Egor

Received: 4 August 2021

Accepted: 24 September 2021

Published: 28 September 2021

Publisher's Note: MDPI stays neutral with regard to jurisdictional claims in published maps and institutional affiliations.

Copyright: (c) 2021 by the authors. Licensee MDPI, Basel, Switzerland. This article is an open access article distributed under the terms and conditions of the Creative Commons Attribution (CC BY) license (https:// creativecommons.org/licenses/by/ $4.0 /)$.

\begin{abstract}
The method of solvothermal by one-step operation has been performed to synthesize of magnetic amine-functionalized sugarcane bagasse biocomposites (SB-MH). The obtained SB-MH contains $62.34 \%$ of $\mathrm{Fe}, 17.8 \mathrm{mmol} / \mathrm{g}$ of amine, and a magnetic property of $19.46 \mathrm{emu} / \mathrm{g}$. The biocomposite surface area increased significantly from 1.617 to $25.789 \mathrm{~m}^{2} / \mathrm{g}$ after amine functionalization. The optimum condition of SB-MH used for $\mathrm{Pb}(\mathrm{II})$ ion removal was achieved at $\mathrm{pH} 5$ for 360 min with adsorption capacity of $203.522 \mathrm{mg} / \mathrm{g}$. The pseudo 2 nd order was well-fitted to the model of $\mathrm{Pb}$ (II) ion adsorption. Meanwhile, other contaminant parameters number of Chemical Oxygen Demand (COD), Total Suspended Solid (TSS), and dye in wastewater were also remarkably reduced by about $74.4 \%, 88.0 \%$, and $96.7 \%$, respectively. The reusability of SB-MH with 4 th repetitions showed only a slight decrease in performance of $5 \%$. Therefore, the proposed magnetic amine-functionalized sugarcane bagasse biocomposites lead to a very potential adsorbent implemented in high scale due to high surface area, easy separation, stable materials and capability to adsorb contaminants from aqueous solution.
\end{abstract}

Keywords: biocomposites; magnetic; $\mathrm{Pb}(\mathrm{II})$ ion; solvothermal; sugarcane bagasse

\section{Introduction}

Recently, the utilization of bio-source materials recovered from biomass has been increasing for research interest. The proper treatment of lignocellulosic materials could produce value-added products such as building block chemicals, sugar, specific polymer, fuel and adsorbent [1,2]. The biomass consisting cellulose, hemicelluloses, and lignin has the capability to adsorb heavy metal ions; and even it can be used as a harmless adsorbent. Furthermore, pre-treatment of biomass with acid solution (nitric acid, sulphuric acid, hydrochloric acid, citric acid) and/or base solution (calcium hydroxide, sodium carbonate, sodium hydroxide) mineral effaces soluble biotic compounds and even may intensify the metal adsorption efficiency [3]. A low-cost farming biomass is sugarcane bagasse. It is a solid part excessed from sugarcane industry. Researchers have applied the cellulose bagasse for biocomposite matrices such as cardanol-formaldehyde composites [4], polyester matrix [5], composite bioplastic [6], and pesticides [7]. The modified sugarcane baggase is also used as adsorbent for dyes removal [8], $\mathrm{CO}_{2}$ adsorption [9], and metal ion adsorption [10]. There are many contaminants in waste water, and one of the dangerous ions is $\mathrm{Pb}(\mathrm{II})$; it is known as a poisonous substance in water. The elevated $\mathrm{Pb}$ (II) ion concentration in drinking water will damage human health, causing things such as mental retardation, kidney failure, physiological flaw, and anemia [11]. Heavy metal removal from 
industrial and urban discharges can decrease their dangerous impact substantially on biota, environment, animal and human health [12]. Another earnest problem around the world is textile dye; whereas $1-15 \%$ of dyes are lost in the emission throughout operation [13]. Dyes are highly poisonous to the watery biota as they are mutagenic and carcinogenic and also cause allergy and skin irritation from a health point of view [14]. Disposal of dyes into water will influence its aesthetic nature and destroy the watery ecosystem due to high concentration of color, Total Suspended Solid (TSS), Biochemical Oxygen Demand (BOD), and Chemical Oxygen Demand (COD) [15].

Several techniques such as ion exchange, reverse osmosis, chemical precipitation, membrane separation, adsorption, and solvent extraction have been used to eliminate heavy metals, dye, and contaminants in waste water [16-19]. The adsorption process is an effective practice, and a low-cost method for removal of $\mathrm{Pb}$ (II) ions from aqueous solutions [20]. However, if the surface modification does not have enough active surface sites, then adsorption is less efficient. Various functional groups as new techniques are developed to make adsorbents, including amine groups, amide, and carboxyl that have elevated selectivity toward poisonous metals [21]. Amine groups are able to absorb a number of metal anions and cations from aqueous solutions due to their specific surface charge [22,23].

Our previous studies have concerned the use of amine rice husk magnetic nanoparticles for metal ion adsorption [20,24]. Those studies are in order to increase the adsorption capacity of metal ions and specific surface area created through modifying of sugarcane bagasse cellulose; hence, the materials become biocomposites with robust magnetic property for easy separation. The preparation of amine magnetic sugarcane bagasse biocomposites was designed to improve the capability and efficiency of adsorption and also degrade other contaminants in waste water. In this study, preparation and characterization of amine-functionalized magnetic sugarcane bagasse biocomposites (SB-MH), adsorption toward the $\mathrm{Pb}$ (II) ions as well as the kinetic study, the removal of COD, TSS, and dye in wastewater by only a one-step adsorption process were inspected. In addition, the capability of biocomposites for used repeatedly in adsorption was also investigated.

\section{Results and Discussions}

\subsection{Amine Functionalized Magnetic Sugarcane Bagasse Biocomposites Characterization}

Initial material of sugarcane bagasse (SB) was delignified and mixed with solvent and chemicals for biocomposite formation. The grinding process caused the damage of SB surface providing high surface area and material porosity; but lignin was still banded to hemicelluloses and cellulose. The preparation steps of amine magnetic sugarcane bagasse biocomposites is presented in Scheme 1.
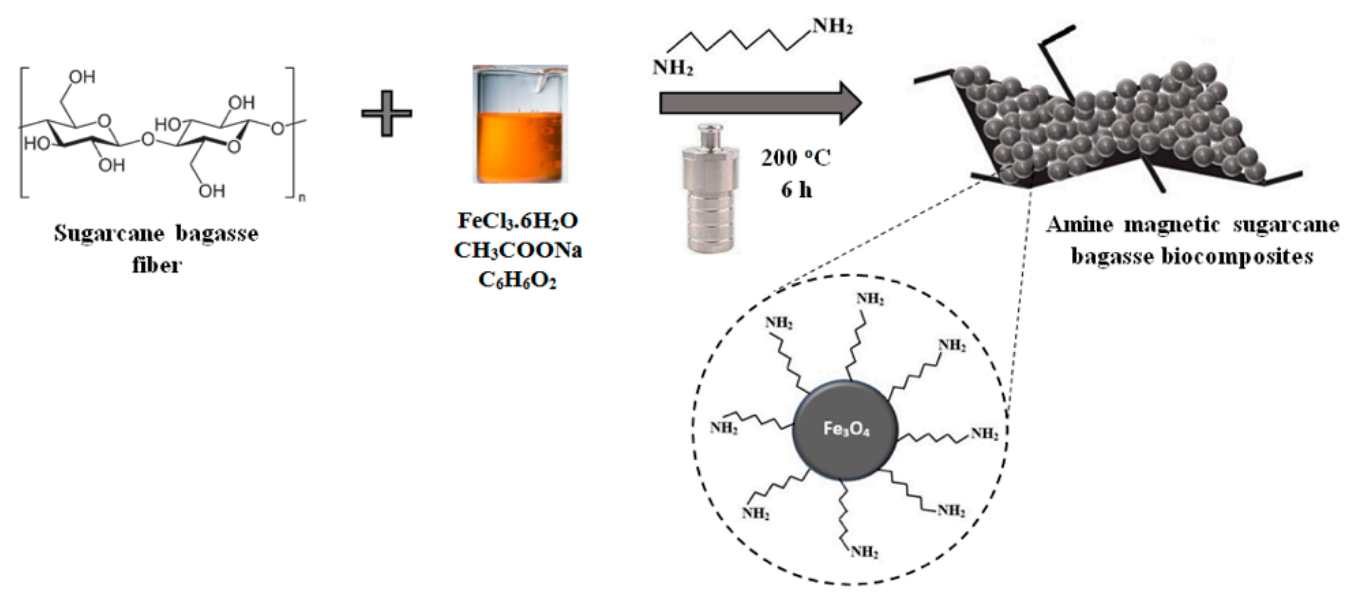

Scheme 1. Preparation of amine magnetic sugarcane bagasse biocomposites (SB-MH). 
The SB structure looks flat and smooth, confirmed by the FE-SEM image as shown in Figure 1a. Furthermore, the breakage of SB from the surface to the inside was inflicted by the process of delignification, as shown in Figure $1 b$; this is called SB-D. The original structure of sugarcane bagasse had a large amount of extractives; they were removed from the surface after delignification [25]. Consequently, the structure of lignocellulose bonds began to break and further became an irregular structure (circle area, Figure 1b). Figure 1c shows amine magnetic sugarcane baggase biocomposites; the magnetic component appeared on the SB-D surface, further named SB-MH. The SB-MH contained about $62.34 \%$ of Fe with apparent associate by magnetic nanoparticles which have a size of around $30-50 \mathrm{~nm}$ (Figure 1c, inset). The hexamethylenediamine as amine source for surface functionalization on biocomposites was successfully deposited as detected at about $17.8 \mathrm{mmol} / \mathrm{g}$. The low porosity of SB-D based on the isotherm of the amount of nitrogen uptake was confirmed by a low surface area with a value of only $1.617 \mathrm{~m}^{2} / \mathrm{g}$. Surprisingly, the surface area of SB-MH significantly increased up to $25.789 \mathrm{~m}^{2} / \mathrm{g}$; it was about 15-fold higher compared to SB-D. These results were also supported by pore volume analysis distribution; the value of SB-D was much smaller than SB-MH- $0.0463 \mathrm{cc} / \mathrm{g}$ compared to $0.115 \mathrm{cc} / \mathrm{g}$, respectively. Thus, the apparent magnetism on the surface of SB-D caused a significant increase in surface area. Similar findings with increases in surface area were also obtained through biocomposite surface functionalization as reported [26,27].
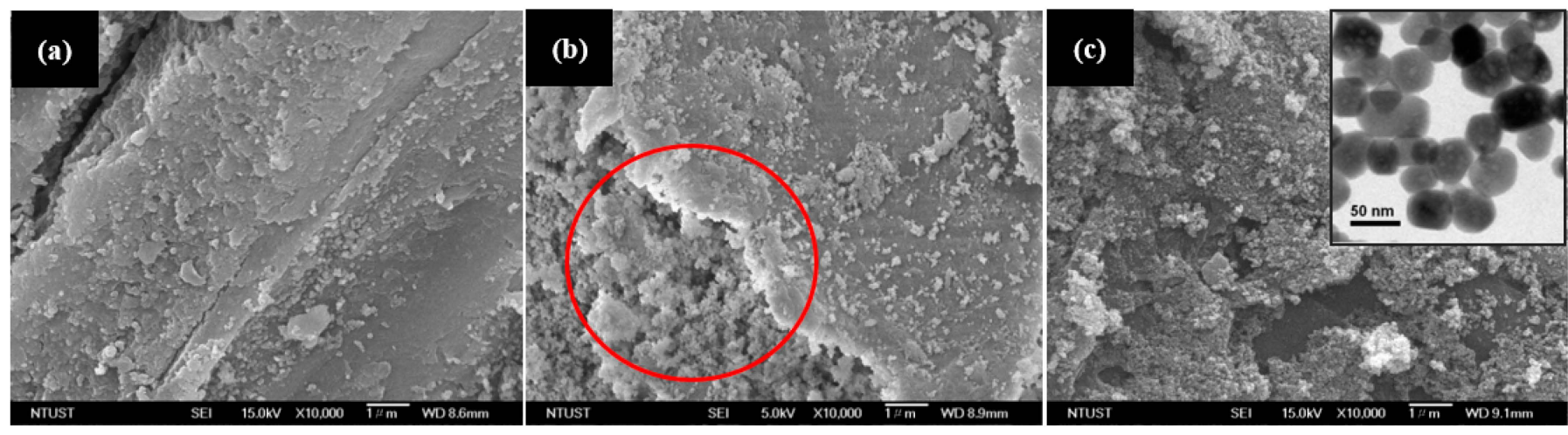

Figure 1. Images of FE-SEM of sugarcane bagasse (a) before treatment (SB), (b) after delignification (SB-D), and (c) aminefunctionalized magnetic sugarcane bagasse biocomposites (SB-MH), ((c), inset) TEM image of magnetic naoparticles.

To prove that SB-D has high crystal structure, it was determined by XRD. Cellulose crystal could be observed at an angle of $2 \theta$ between $20^{\circ}-40^{\circ}$. Cellulose consists of millions of microfibrils that contain an amorphous section; it is formed from a cellulose bond with flexible masses and crystalline. The part of the crystal is isolated to produce the finest microcrystalline cellulose. The characterization of the peak of SB and SB-D that contained cellulose fiber was identified at $16.78^{\circ}$ for amorphous and $21.69^{\circ}$ for crystal formation at 2 tetha $\left({ }^{\circ}\right)$ (Figure 2a). It was also be proven by SB-D that there was a high intensity of the peak compared to SB. Furthermore, due to loss of hemicelluloses and lignin content, the amorphous structure was mostly changed to be crystalline cellulose. The crystallinity index (CrI) of SB-D increased up to $61.54 \%$, and this result was similar to the result of alkaline treatment of sugarcane bagasse with a crystallinity index of about $63.15 \%$ [28]. Based on the XRD result, the establishment of magnetic nanoparticles was also identified with appearance peaks at $36^{\circ}, 43^{\circ}$, and $57^{\circ}$ as magnetite of $\mathrm{Fe}_{3} \mathrm{O}_{4}$. Those peaks were matched with the crystalline magnetite according to the standard pattern crystal data (JCPDS card 39-0664). 

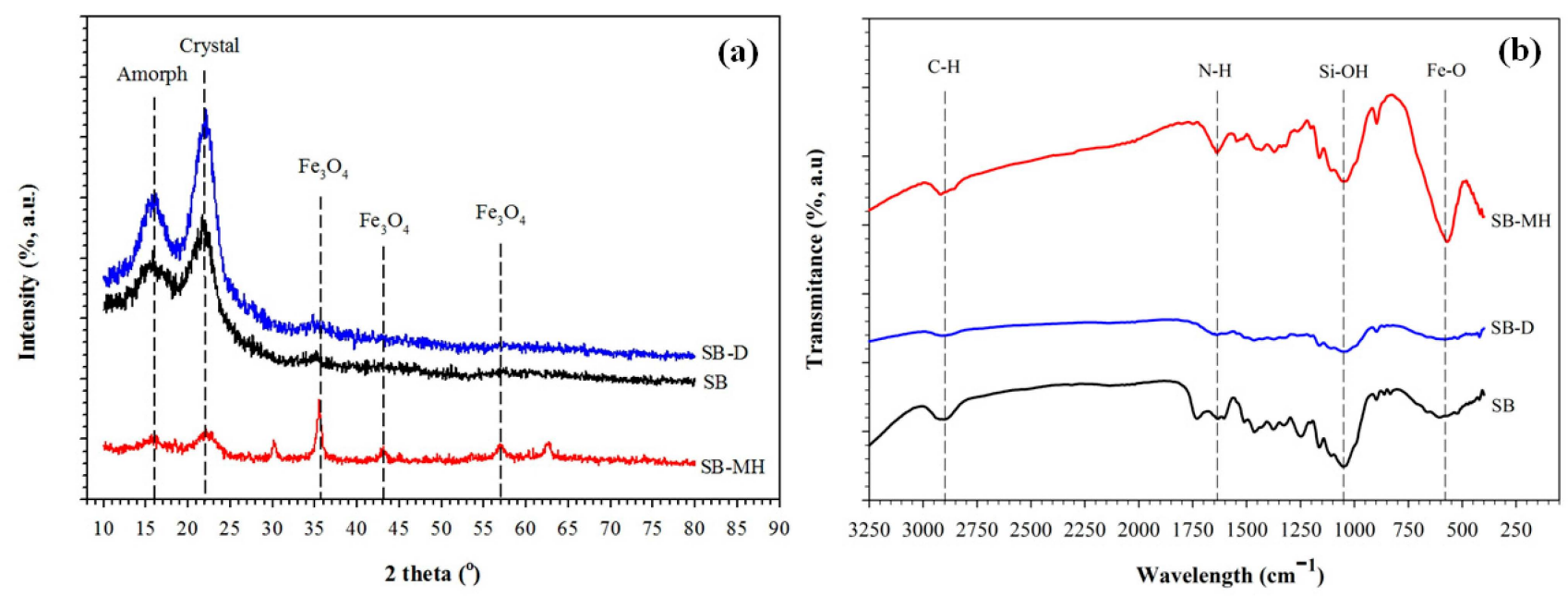

Figure 2. (a) X-Ray Diffraction (XRD) pattern and (b) FT-IR spectrum of sugarcane bagasse (SB), SB after delignification (SB-D) and biocomposites of amine magnetic sugarcane bagasse (SB-MH).

The FT-IR spectrum was investigated for the functional groups on materials. The peak at $2900 \mathrm{~cm}^{-1}$ was detected as the stretching vibrations of $\mathrm{C}-\mathrm{H}$ for bonding structure of SB-D and SB (Figure 2b). The amine group was identified at $1640 \mathrm{~cm}^{-1}$ individually for SB-MH. The Fe-O stretching band for $\mathrm{Fe}_{3} \mathrm{O}_{4}$ was detected at $580 \mathrm{~cm}^{-1}$. The wavenumber at $1050 \mathrm{~cm}^{-1}$ confirmed the presence of the O-H and Si-OH band and belongs to SB and SB-D. In addition, peaks at 1260 and $1525 \mathrm{~cm}^{-1}$ indicated the lignin aromatic for the $\mathrm{C}=\mathrm{C}$ bond on SB; however, those peaks did not exist on SB-MH. This finding is reasonable because the content of lignin was decreased and cellulose was detached [28].

Furthermore, SB-MH with the magnetite $\left(\mathrm{Fe}_{3} \mathrm{O}_{4}\right)$ phases has superparamagnetic properties and consequently is able to react with the outward magnetic field. This character will facilitate an easy separation. To prove the saturation magnetization measurement, it is necessary to conduct the SQUID analysis at room temperature. Figure 3a shows the proceeds of ferromagnetic behavior for the naked amine magnetic nanoparticle $(\mathrm{MH})$ and the SB-MH. The magnetic saturation values of MH and SB-MH are 67.94 and $19.46 \mathrm{emu} / \mathrm{g}$, respectively. The reduction number of the saturation value for SB-MH was about $71.4 \%$; this is most likely associated to the cellulose amount in SB. A similar result was also obtained for the rice husk magnetic biocomposites [20,29]. The biocomposite response to the external magnetic field which contains $0.15 \mathrm{~g}$ of fiber in $5 \mathrm{~mL}$ of water takes $6 \mathrm{~s}$ apart from the solution (Figure 3a, inset). The magnetic property of materials may influence the capability as an adsorbent by increasing the adsorption capacity against a large range of biological toxins [30].

The thermal gravimetric method was applied to study the typical degradation of biocomposites carbonized up to $1000^{\circ} \mathrm{C}$. From Figure $3 \mathrm{~b}$, the SB-D clearly showed a twostage pattern with the decrease in weight. The organic compound evaporation occurred in the range of $30-200{ }^{\circ} \mathrm{C}$ (1st stage). Then, the weight loss in the 2nd stage was indicated at 200-600 ${ }^{\circ} \mathrm{C}$ as shown for cellulose, lignin and hemicelluloses with the degradation until $95.7 \%$. This typical degradation is similar to that of other lignocellulose materials [31]. On the other hand, the TG curve for SB-MH appears to be quite resistant to temperature, as the evaporation of water only take about $5.15 \%$ weight loss at $200{ }^{\circ} \mathrm{C}$ for the 1 st stage. On further observation, the SB-MH curve was the decomposition of lignocelluloses material and amine groups up to $600{ }^{\circ} \mathrm{C}$ with the remaining material of $62.34 \%$. Interestingly, the biocomposites of amine-functionalized magnetic sugarcane bagasse took place in stable conditions after $600^{\circ} \mathrm{C}$; it is plausible due to the presence of magnetic nanoparticles. Even more, the SB-MH remained in a residual amount of weight about $34.86 \%$ higher than that for SB-D. 

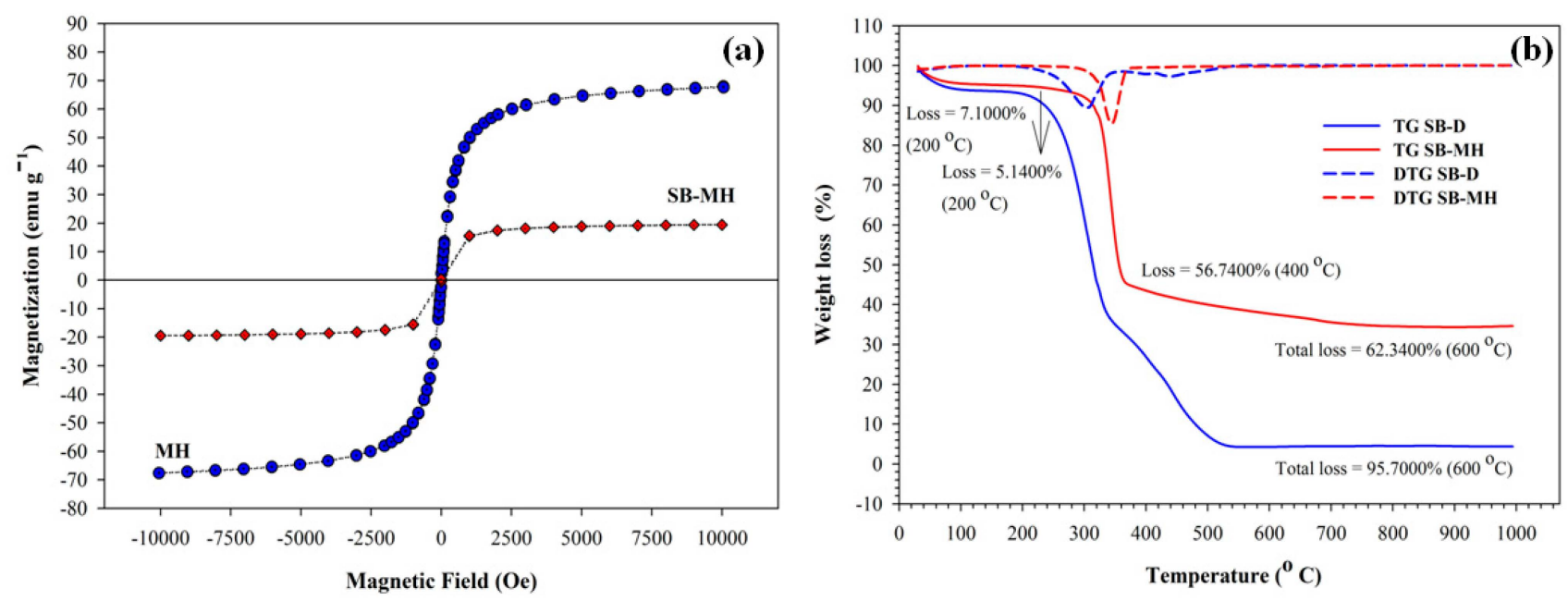

Figure 3. (a) Magnetization property of amine magnetic (MH) and amine magnetic sugarcane bagasse biocomposites (SB-MH) at room temperature; (b) Thermogravimetry (TG) and Derivative Thermogravimetry (DTG) curves of delignified sugar cane bagasse (SB-D) and amine magnetic sugarcane bagasse biocomposites (SB-MH).

\subsection{Kinetic Study of Pb(II) Ion Adsorption onto Amine Functionalized Magnetic Sugarcane Bagasse Biocomposites}

The kinetic behaviour and adsorption capacity are significant aspects to study the heavy metal ion adsorption process, especially for new potential adsorbents. For this study, the SB-M also was used as a control to observe the effects of amine functionalization on biocomposites to adsorption capacity. The adsorption kinetics models for pseudo 1st (Equation (1)) and pseudo 2nd model (Equation (2)) were applied to study the mechanism of biocomposites [32,33].

$$
\begin{gathered}
\mathrm{Q}_{\mathrm{t}}=\mathrm{Q}_{\mathrm{e}}\left(1-\mathrm{e}^{-\mathrm{k}_{1} \mathrm{t}}\right) \\
\frac{\mathrm{t}}{\mathrm{Q}_{\mathrm{t}}}=\frac{\mathrm{t}}{\mathrm{Q}_{\mathrm{e}}}+\frac{\mathrm{t}}{\mathrm{k}_{2} \mathrm{Q}_{\mathrm{e}}^{2}}
\end{gathered}
$$

$\mathrm{Q}_{\mathrm{e}}(\mathrm{mg} / \mathrm{g})$ is the adsorbed amount of $\mathrm{Pb}(\mathrm{II})$ ions at equilibrium and $\mathrm{Q}_{\mathrm{t}}(\mathrm{mg} / \mathrm{g})$ is the adsorbed amount of $\mathrm{Pb}(\mathrm{II})$ ions at time $\mathrm{t}$. The $\mathrm{k}_{1}\left(\mathrm{~min}^{-1}\right)$ is the pseudo 1st order rate constant and $\mathrm{k}_{2}$ (g/mg min) is the pseudo 2 nd order rate constant for the adsorption.

The profile of $\mathrm{Pb}$ (II) ion adsorption capacity on SB-M and SB-MH is shown in Figure 4. Both types of adsorbents have the ability to bind $\mathrm{Pb}$ (II) ions with an increase in adsorption capacity up to 150.628 and $203.522 \mathrm{mg} / \mathrm{g}$ for SB-M and SB-MH, respectively. Further, the adsorption capacity became constant, indicated by an equilibrium phase achieved. The rapid increase in adsorption capacity at the beginning process was possible due to the high $\mathrm{Pb}(\mathrm{II})$ ion concentration. Furthermore, the availability of empty sites on the adsorbent also caused a high rate of adsorption. The adsorption equilibrium time of $\mathrm{Pb}$ (II) ions for both SB-M and SB-MH was achieved in $360 \mathrm{~min}$. At this condition, SB-MH has a larger adsorption capacity of about $25.99 \%$ compared to SB-M. The adsorption of SB-M at pH 5 led to deprotonation of the magnetic surface into $\mathrm{FeO}^{-}$. The adsorption of $\mathrm{Pb}$ (II) ions occurred due to negative charge surface formation and electrostatic interaction to capture the $\mathrm{Pb}(\mathrm{II})$ ions [1]. In addition, the surface area of SB-MH was 2.82-fold higher than SB-M. This result proved that the presence amine groups on biocomposites enhanced the adsorption capacity of $\mathrm{Pb}$ (II) ions. Due to formation of $-\mathrm{NH}_{3}{ }^{+}$, the positive surface charge of the magnet was stable. The water solubility of amine increased the hydrogen bonding as well as the lone electron pair, then capturing the $\mathrm{Pb}(\mathrm{II})$ ion [24]. This confirms that the amine functionalized on biocomposites has a significant effect on adsorption capacity. 


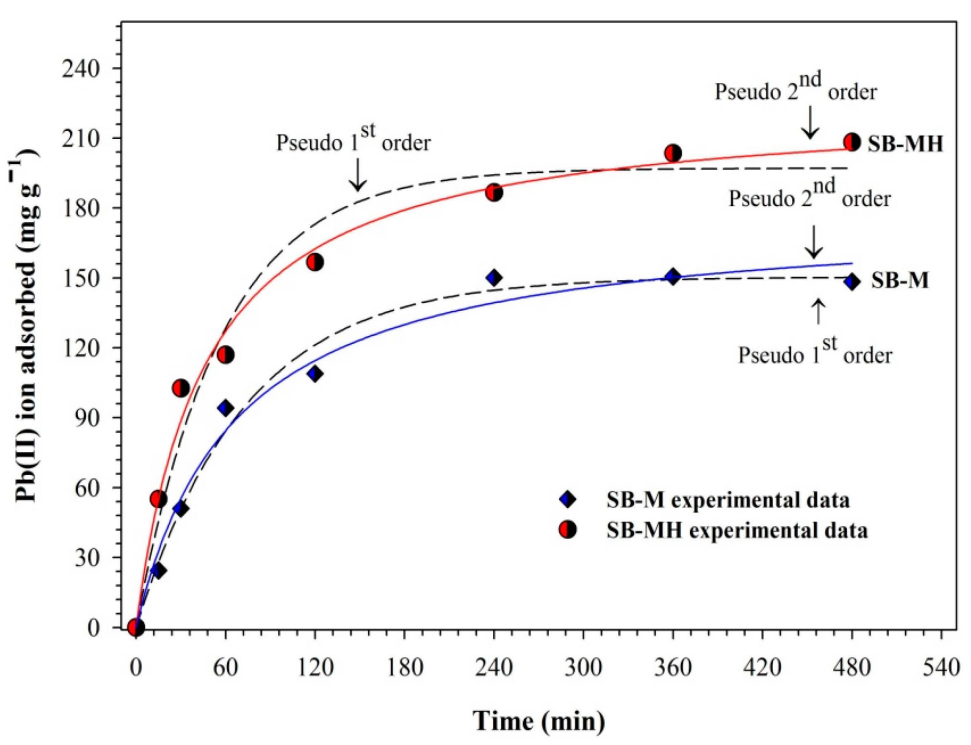

Figure 4. The kinetic profile of $\mathrm{Pb}(\mathrm{II})$ ion adsorption by $\mathrm{SB}-\mathrm{M}$ and $\mathrm{SB}-\mathrm{MH}$ at various contact times. Conditions: volume sample of $200 \mathrm{~mL}, \mathrm{pH}$, shaking rate of $150 \mathrm{rpm}$.

Based on the result of adsorption fitting data (Table 1), the adsorption kinetics of $\mathrm{Pb}$ (II) ions for SB-MH is in accordance with the pseudo 2nd order adsorption kinetics model with an $R^{2}$ value of 0.99 ; it means that the control of adsorption process is chemical adsorption. The mechanism of the pseudo 2nd order adsorption process is described by assuming that the determinant of the reaction rate is a chemical entrapment process including the electron exchange between adsorbate and adsorbent or inter-valence force. This finding is in accordance with the results of other studies [34]. Furthermore, the occurrence of chemical adsorption was mostly related to presence of amine groups on the adsorbent. In addition, the affinity of the adsorbent site will be stronger to metal ions with a smaller $\mathrm{k}$ value; hence, the adsorption process is faster and more efficient [35].

Table 1. $\mathrm{Pb}$ (II) Ion Adsorption Kinetics Parameters using SB-M and SB-MH.

\begin{tabular}{cccc}
\hline \multirow{2}{*}{ Adsorbent } & Parameters & \multicolumn{2}{c}{ Model of Kinetic } \\
\cline { 3 - 4 } & & Pseudo 1st Order & Pseudo 2nd Order \\
\hline \multirow{2}{*}{ SB-M } & $\mathrm{Q}_{\mathrm{e}}(\mathrm{mg} / \mathrm{g})$ & 150.3850 & 177.8290 \\
& $\mathrm{k}_{1}\left(\mathrm{~s}^{-1}\right)$ & 0.0137 & 0.000084 \\
& $\mathrm{R}^{2}$ & 0.9880 & 0.9840 \\
\hline \multirow{2}{*}{ SB-MH } & $\mathrm{Q}_{\mathrm{e}}(\mathrm{mg} / \mathrm{g})$ & 197.0850 & 225.0960 \\
& $\mathrm{k}_{1}\left(\mathrm{~s}^{-1}\right)$ & 0.0180 & 0.00009 \\
& $\mathrm{R}^{2}$ & 0.9690 & 0.9910 \\
\hline
\end{tabular}

On the other hand, the kinetics adsorption for SB-M is more appropriate to follow pseudo 1 st order kinetics model with $R^{2}$ value of 0.9881 and qe of $150.385 \mathrm{mg} / \mathrm{g}$. The value of maximum adsorption capacity was also similar to the experimental result $(150.628 \mathrm{mg} / \mathrm{g})$. The difference in adsorption kinetic models for SB-M and SB-MH can be related to the presence of an amine group on SB-MH. The amine groups on bicomposites affect the surface charge of biocomposites to become positive $\left(-\mathrm{NH}_{3}{ }^{+}\right)$. The water solubility of amine is higher due to hydrogen bonds involved in these lone electron pairs, then interacting with $\mathrm{Pb}$ (II) ions in solution. The chemical adsorption occurred faster than that for SB-M. Therefore, the group of amines on biocomposites enhanced the capacity of adsorption toward $\mathrm{Pb}(\mathrm{II})$ ions. 


\subsection{Effect of $\mathrm{pH}$ on $\mathrm{Pb}(\mathrm{II})$ Ion Adsorption, Chemical Oxygen Demand (COD), Total Suspended Solid (TSS), and Dyes Adsorption}

The $\mathrm{pH}$ of solution can increase or inhibit the adsorption of ions by changing the properties of the adsorbent surface charge; $\mathrm{pH}$ solution is one of the significant factors to affect the adsorption. The $\mathrm{Pb}$ (II) ion adsorption process can be in the form of ion exchange, surface complex formation or electrostatic interactions between $\mathrm{Pb}$ (II) ions and the adsorbent [36]. Figure 5a shows the effect of $\mathrm{pH}$ on adsorption of $\mathrm{Pb}(\mathrm{II})$ ions. The adsorption process took place optimally for SB-M and SB-MH at pH of 5 with adsorption capacity of 148.379 and $208.302 \mathrm{mg} / \mathrm{g}$, respectively. The concentration of hydrogen ions at solution with lower $\mathrm{pH}(\sim 5)$ leads to a higher value and this causes hydrogen ions to contend with $\mathrm{Pb}(\mathrm{II})$ ions for the active site; consequently, the presence of hydrogen ions enhances the adsorption capacity of $\mathrm{Pb}$ (II) ions [37]. On the other hand, increasing $\mathrm{pH}$ value causes the gradual decrease in the hydrogen ion concentration and thus the adsorbent surface was deprotonated. At this condition, the bonding occurs between $\mathrm{Pb}(\mathrm{II})$ ions and $\mathrm{OH}$ - anions to form $\mathrm{Pb}(\mathrm{OH})_{2}$. The increase value of $\mathrm{pH}(>5.8)$ causes the $\mathrm{Pb}$ (II) ions to be hydrolyzed in solution and further configures hydroxides [37]. The highest capacity of $\mathrm{Pb}$ (II) ion adsorption occurs at $\mathrm{pH} 5$ and subsequently decreases; the soluble $\mathrm{Pb}(\mathrm{OH})_{2}$ species become dominant and then precipitation of $\mathrm{Pb}(\mathrm{OH})_{2}$ occurs at $\mathrm{pH}$ above 6.5 [38]. The optimal adsorption process is carried out in acidic conditions; $\mathrm{pH} 5$ is the optimal condition for the adsorption process in this study. This condition also could be applied for metal ion removal in waste water.
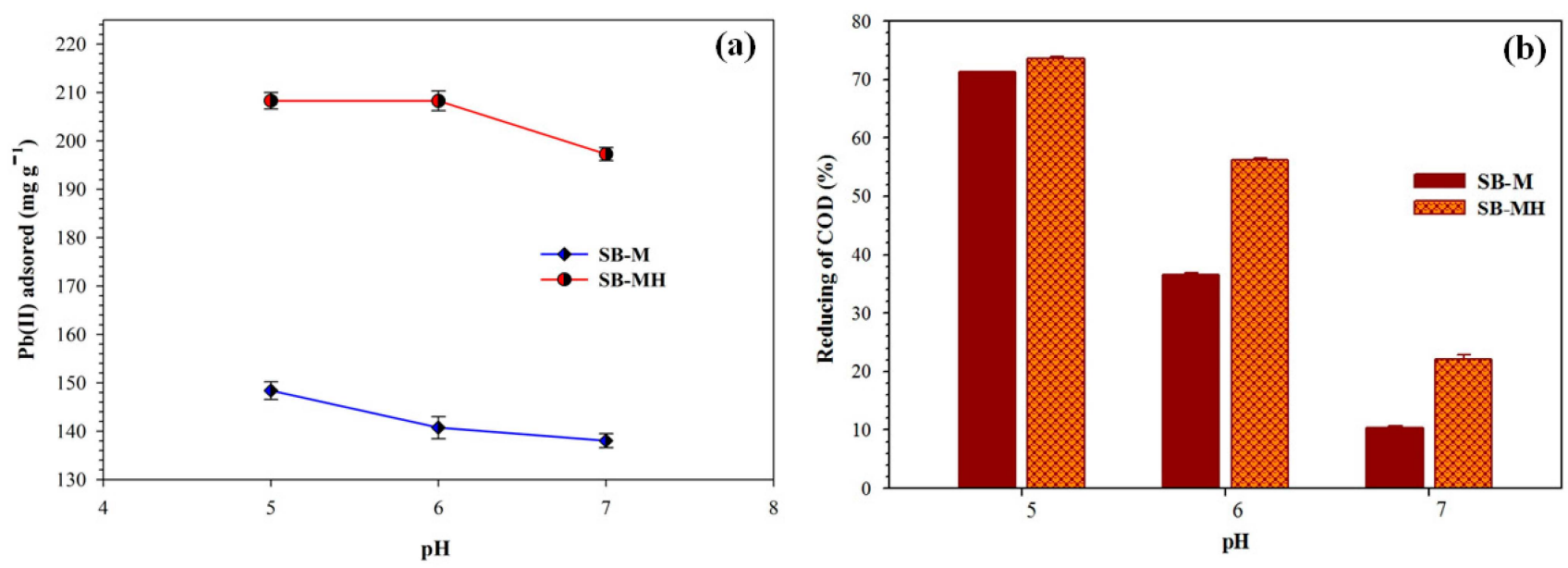

Figure 5. (a) The concentration of $\mathrm{Pb}(\mathrm{II})$ ion adsorption capacity and (b) reduction of $\mathrm{COD}$ on adsorption at various $\mathrm{pH}$ with a sample volume of $300 \mathrm{~mL}, 360 \mathrm{~min}$, shaking rate of $150 \mathrm{rpm}$.

COD concentration is influenced by role of the $\mathrm{pH}$ solution; the adsorption phenomenon is correlated to the ion exchange process. $\mathrm{pH}$ adjustment of the solution influences the adsorbent surface charge, ionization degree, stability and color intensity of the compounds in solution [39]. Figure $5 \mathrm{~b}$ shows $\mathrm{COD}$ reduction at various $\mathrm{pH}$. The largest reduction of COD occurred at $\mathrm{pH}$ of 5 with a value of $71.29 \%$ and $73.63 \%$ for SB-M and SB-MH, respectively. Generally, COD value decreased with increasing $\mathrm{pH}$. For higher $\mathrm{pH}$, the lower adsorption occurs due to an increase in the diffusion barrier of organic ions as well as the abundance of $\mathrm{OH}$ - ions; this causes the competition between organic molecules and the adsorbent surface [40]. At low $\mathrm{pH}$, the positively charged group of organic molecules is bound by the attraction of electrostatic forces to the negative charge of the adsorbent surface. This is in keeping with the previous studies where low $\mathrm{pH}$ solutions increased the COD reduction using an adsorbent made from bagasse [41].

Besides having an effect on COD reduction, the adsorbent also has capability to degrade TSS. Stable suspended particles can be neutralized through a destabilization process with the addition of a positive charge from the adsorbent, afterward the energy 
resistance is reduced and a flock core is formed. The existence of a positive charge that is able to absorb negative charges on suspended particles surface causes the repulsion force between suspended particles in the waste to weaken. The comparison of TSS reduction in differences of $\mathrm{pH}$ is presented in Figure 6a, and the decrease in TSS is not very significant for all adsorbents. Another effect on SB-M and SB-MH adsorption is dye reduction (Figure $6 \mathrm{~b}$ ). The high dye reduction for SB-M and SB-MH occurred at $\mathrm{pH}$ 6. Dye reduction number was obtained at about $92.56 \%$ and $96.69 \%$ for SB-M and SB-MH, respectively. The reduction color for dye was observed before adsorption and after adsorption by using SB-M and SB-MH (Figure $6 \mathrm{~b}$, inset). It is clear that the original color (purple) disappears, becoming a clear solution after adsorption. The decrease of dye intensity in solution is probably due to protonation that would be the specific cause for the enhancement of electrostatic interaction between the negatively charged anions in the molecule of dye and the positive charge of the adsorbent active site [42].
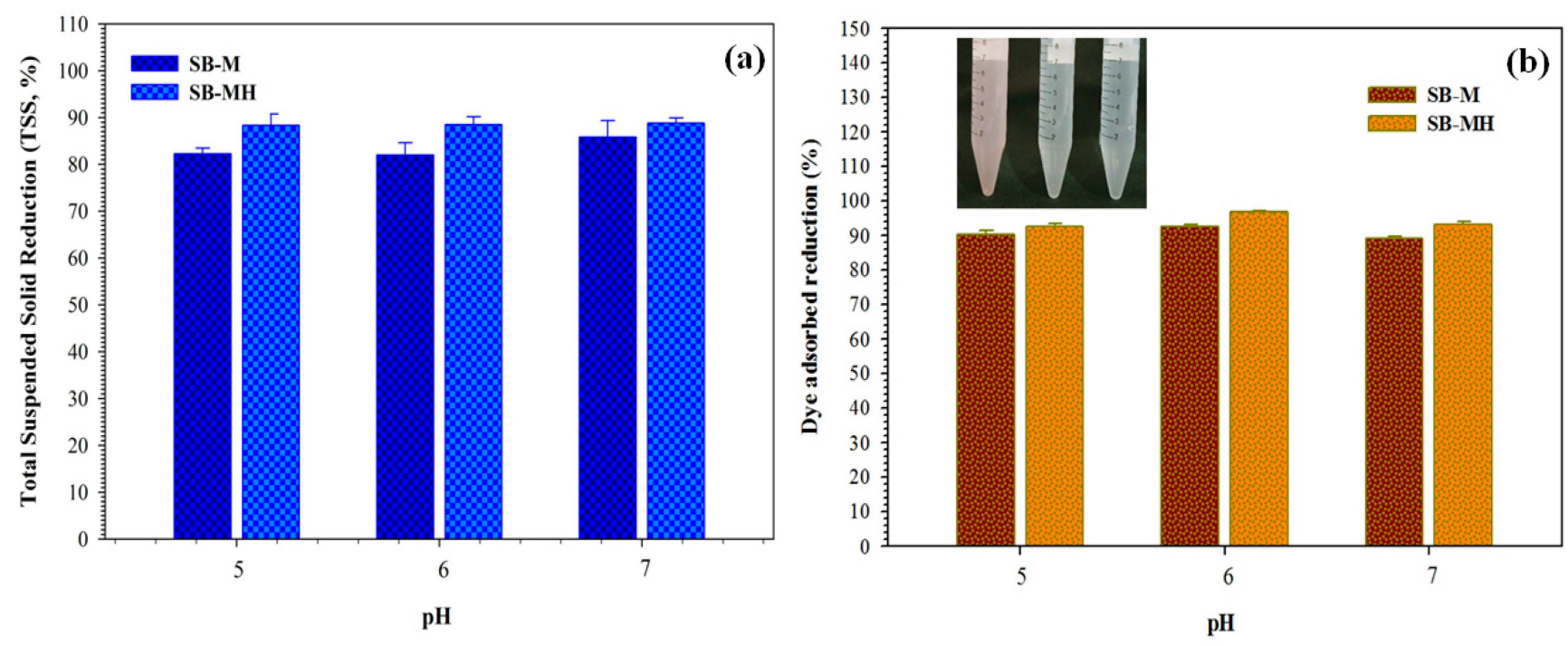

Figure 6. (a) TSS and (b) dye reduction related to the $\mathrm{pH}$ variations in the adsorption process with a sample volume of $300 \mathrm{~mL}, 360 \mathrm{~min}$, shaking rate of $150 \mathrm{rpm}$.

In fact, the hydrogen ion concentration in the solution with $\mathrm{pH}$ of 5 is higher and this causes the hydrogen ions to compete with another contaminant for the active site. Hence, the presence of hydrogen ions can reduce the adsorption capacity of dye. Although influenced by the $\mathrm{pH}$ in solution, in this study the decrease in dye intensity at various $\mathrm{pH}$ did not show significant difference.

\subsection{Reusability Performance of Amine Magnetic Sugarcane Bagasse Biocomposites}

In order to evaluate the regeneration of biocomposites, $0.01 \mathrm{M} \mathrm{HCl}$ was elected as the effluent for $\mathrm{Pb}$ (II) ion desorption. The regeneration using $0.01 \mathrm{M} \mathrm{HCl}$ provides better desorption for the reuse process. As reported, the optimum desorption efficiency of the $\mathrm{Pb}$ (II) ion was obtained at value of $91 \%$ with $0.01 \mathrm{HCl}$ [43]. At low $\mathrm{pH}$, the hydrogen ions were combined with the ligands, then took place the adsorption site of the $\mathrm{Pb}$ (II) ion. Spontaneously, the $\mathrm{Pb}(\mathrm{II})$ ion will be released into solution. Desorption using $\mathrm{HCl}$ allows $\mathrm{Pb}$ (II) ions to be able to bind $\mathrm{Cl}$ - to form $\mathrm{PbCl}_{2}$; thus, adsorbent can be reused for the next process of adsorption. The adsorption performance of $\mathrm{Pb}(\mathrm{II})$ ions using SB-M and SB-MH was conducted in four cycles (Figure 7). The desorption efficiency for SB-M and SB-MH was about $92.11 \%$ and $96.96 \%$, respectively. For both adsorbents of SB-M and SB-MH, the capacity of the $\mathrm{Pb}$ (II) ion adsorption during the reusable process decreased to be only below $10 \%$ after 4 th cycles, i.e., $7.89 \%$ and $3.84 \%$, respectively. The decreasing of adsorption capacity of adsorbents in reusability process also occurred in previous studies for biocomposites [20]. Derivation occurs due to unalterable ions of partial functional 
groups on the surface of biocomposites, thus affecting the subtraction in the number of sites and weakening the electrostatic interaction between the adsorbate and adsorbent [44]. A slight subtraction in the capacity of adsorption is owing to the incomplete desorption of divalent metal ions from the surface of adsorbent and also due to the reduction of some surface functional groups such as $-\mathrm{OH}$ and the amine group as well as the leaching of weak inorganic materials $\left(\mathrm{Fe}_{3} \mathrm{O}_{4}\right)$ [45].

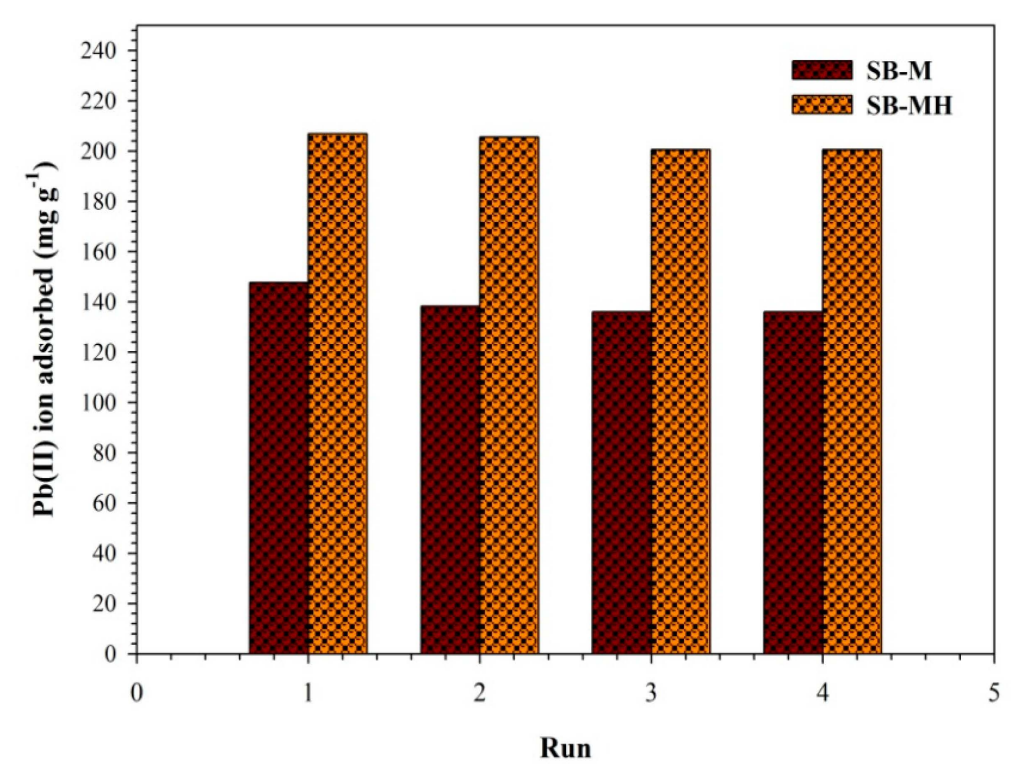

Figure 7. Repetition of the adsorbent in adsorption for SB-M and SB-MH with a sample volume of $300 \mathrm{~mL}, 360 \mathrm{~min}$, shaking rate of $150 \mathrm{rpm}$.

This shows that the amine magnetic sugarcane bagasse biocomposites have potential as a reusable adsorbent. Based on this study, the SB-MH has a better ability than SB-M including the process of reusing biocomposites. In other words, SB-MH is a more effective adsorbent for wastewater treatment, including $\mathrm{Pb}$ (II) ion removal, reducing of $\mathrm{COD}$, TSS and dye in aqueous solution. These advantages make amine magnetic biocomposites more effective and confirm their suitability as adsorbents for a wide range of pollutant in aqueous solutions.

\section{Materials and Methods}

\subsection{Materials}

The sugarcane bagasse was procured from a sugarcane juice seller at Banjarbaru, South Kalimantan, Indonesia. Wastewater containing dye was obtained from Sasirangan textile industry in Banjarbaru, Indonesia. The sasirangan textile contains TSS and COD of about 0.252 and $38.46 \mathrm{mg} / \mathrm{L}$, respectively. The color absorption intensity by UV was identified about 0.6 for 3 times dilution. Lead (II) nitrate $\left(\left(\mathrm{Pb}\left(\mathrm{NO}_{3}\right)_{2}\right)\right.$, iron trichloride hexahydrate $\left(\mathrm{FeCl}_{3} \cdot 6 \mathrm{H}_{2} \mathrm{O}\right)$, ethylene glycol $\left(\mathrm{C}_{2} \mathrm{H}_{6} \mathrm{O}_{2}\right)$, sodium acetate anhydrous $\left(\mathrm{C}_{2} \mathrm{H}_{3} \mathrm{NaO}_{2}\right)$, hexamethylenediamine $\left(\mathrm{C}_{6} \mathrm{H}_{16} \mathrm{~N}_{2}\right)$, hydrochloric acid $(\mathrm{HCl})$, ethanol $\left(\mathrm{C}_{2} \mathrm{H}_{5} \mathrm{OH}\right)$, and caustic soda $(\mathrm{NaOH})$ were purchased from Sigma Aldrich (Singapore).

\subsection{The Sugarcane Bagasse Delignification}

Tap water was used for washing sugarcane bagasse (SB) and dried at $80^{\circ} \mathrm{C}$ for $3 \mathrm{~h}$ in an oven. The dried SB was grinded to form SB powder which has 60 mesh in size. The process of delignification was performed by mixing $1 \% \mathrm{NaOH}(w / v)$ and $45 \% w / v$ of $\mathrm{SB}$ in the flask at $80^{\circ} \mathrm{C}$ for $2 \mathrm{~h}$ under stirring. After cooling at room temperature, SB were filtered and washed with deionized (DI) water until the filtrate becomes neutral $\mathrm{pH}$. Finally, the delignified SB (SB-D) was obtained by drying for $6 \mathrm{~h}$ at $80^{\circ} \mathrm{C}$ in an oven. 


\subsection{Synthesis of Amine Magnetic Sugarcane Bagasse Biocomposites}

One of the methods for preparation of amine-functionalized magnetic nanoparticle biocomposites is solvothermal reaction [20]. Initially, $0.8 \mathrm{~g}$ of iron trichloride hexahydrate and $1.6 \mathrm{~g}$ of sodium acetate anhydrous were placed in a beaker glass and $0.5 \mathrm{~g}$ of SB-D dissolved in $24 \mathrm{~mL}$ of ethylene glycol was poured to the flask by intense stirring for $10 \mathrm{~min}$ at $50{ }^{\circ} \mathrm{C}$. Further, $7 \mathrm{~mL}$ of hexamethylenediamine was added into mixture. Finally, the mixture solution was placed in a Teflon Stainless Steel Autoclave and underwent a reaction for $6 \mathrm{~h}$ at $200{ }^{\circ} \mathrm{C}$. Further, the solution was cooled at a room temperature. An external magnet field was used to collect the biocomposites from the solution and then rinsed with DI water followed by ethanol three times. The obtained material (SB-MH) was stored in DI water for further use. As a control, magnetic sugarcane bagasse biocomposites without addition of hexamethylenediamine (SB-M) were also produced.

\subsection{Adsorption of Pb(II) Ion, Total Suspended Solid (TSS), Chemical Oxygen Demand (COD) and} Dye onto Amine Functionalized Magnetic Nanoparticles Biocomposites

The adsorption capacity of biocomposites was conducted in a batch adsorption experiment to adsorb $\mathrm{Pb}$ (II) ions using wastewater of textiles as a dilution with initial concentration of $\mathrm{Pb}$ (II) of $100 \mathrm{ppm}$. The contact time (15, 30, 60, 120, 180, 240 and $360 \mathrm{~min})$ and $\mathrm{pH}(5$, 6 and 7) effects on the adsorption process were observed comprehensively. The desired value of $\mathrm{pH}$ was obtained by adding of $0.1 \mathrm{M} \mathrm{NaOH}$. A total of $200 \mathrm{~mL}$ of certain $\mathrm{Pb}$ (II) ion concentrations was added to a weight amount of adsorbent. Then, the solution was shaken for various times and $\mathrm{pH}$ at room temperature to get the equilibrium condition. The external magnetic field was used to separate the solution for $2 \mathrm{~min}$. Atomic Adsorption Spectrophotometer (AAS) was detected to calculate the remaining concentration of $\mathrm{Pb}$ (II) ions. The duplicated data and average value were taken for this study. The capability of biocomposites for repeated use in adsorption was also investigated; desorption of the $\mathrm{Pb}$ (II) ion-loaded SB-MH and SB-M was done by shaking for $4 \mathrm{~h}$ in $0.1 \mathrm{~N} \mathrm{HCl}$. Regenerated SB-MH and SB-M were used as an adsorbent for the next cycle after washing with DI water until filtrate $\sim \mathrm{pH} 7$. The capacity of adsorption was determined by applying the equation:

$$
\mathrm{q}_{\mathrm{e}}=\left(\mathrm{C}_{\mathrm{o}}-\mathrm{C}_{\mathrm{e}}\right) \frac{\mathrm{V}}{\mathrm{m}}
$$

where $\mathrm{Co}\left(\mathrm{mg} \mathrm{L}^{-1}\right)$ is the concentration of beginning $\mathrm{Pb}(\mathrm{II})$ ion and $\mathrm{Ce}\left(\mathrm{mg} \mathrm{L}^{-1}\right)$ is the equilibrium concentration of the $\mathrm{Pb}(\mathrm{II})$ ion. $\mathrm{V}(\mathrm{L})$ is the solution volume and $\mathrm{m}(\mathrm{g})$ is the amount of adsorbent.

\subsection{Characterization}

A transmission electron microscopy (TEM) image was taken using a Hitachi H-800 transmission electron microscope (Tokyo, Japan). Surface morphology of the sample was tested by Field-emission scanning electron microscopy (FE-SEM, JEOL JSM-6500F, JEOL Ltd., Tokyo, Japan) where all samples were sputter-coated by platinum. The X-Ray Fluorescence (XRF) observation by the PANalytical/Minipal machine (Malvern, London, UK) was used for detecting elements in the sample. The X-ray diffraction (XRD) measurement was investigated using a Rigaku D/MAX-B X-ray diffractor (Rigaku Co., Tokyo, Japan) meter equipped with Copper K-alpha $(\mathrm{CuK} \alpha)$ radiation. The operation voltage worked at $40 \mathrm{kV}$ and the current for machine worked at $100 \mathrm{~mA}$. Autosorb-1 instrument (Anton Paar Quanta Tec. Inc., Boynton Beach, FL, USA) was used to evaluate Brunauer-Emmet-Teller (BET) surface area equipped with the nitrogen adsorption-desorption using a Quantachrome. The magnetic property was investigated by the superconducting quantum interference device (SQUID, LakeShore 7307, Lake Shore Cryotronics Inc., Westerville, OH, USA) magnetometer. The functional groups on the sample were investigated by using Fourier transform infrared spectrometry (FT-IR, Bio-rad, Digilab FTS-3500Agilent Digilab, CA, USA). Thermal gravimetric analysis (TGA) was used to study the degradation of material (Perkin Elmer, 
Waltham, MA, USA) in $\mathrm{N}_{2}$ atmosphere flow $10{ }^{\circ} \mathrm{C} / \mathrm{min}$ at $30-1000^{\circ} \mathrm{C}$. The degradation of the material component was studied via mass reduction from curves of TGA.

\subsection{Analysis}

The amine content on biocomposites was calculated by the retro-titration method [46]. The $50 \mathrm{mg}$ of sample was put in $25 \mathrm{~mL}$ of $0.01 \mathrm{M} \mathrm{HCl}$ and shaken for $2 \mathrm{~h}$ at room temperature. After filtration, the filtrate was titrated by $0.01 \mathrm{~N} \mathrm{NaOH}$, and the calculation of amine group concentration was determined by applying the equation:

$$
\mathrm{C}_{\mathrm{NH}_{2}}\left[\frac{\left(\mathrm{C}_{\mathrm{HCl}} \times \mathrm{V}_{\mathrm{HCl}}\right)-\left(5 \mathrm{C}_{\mathrm{NaOH}} \times \mathrm{V}_{\mathrm{NaOH}}\right)}{\mathrm{m}_{\text {sample }}}\right]
$$

where $\mathrm{C}_{\mathrm{HCl}}$ is the $\mathrm{H}_{\mathrm{Cl}}$ solution concentration $(\mathrm{mmol} / \mathrm{L}) . \mathrm{C}_{\mathrm{NaOH}}$ is the $\mathrm{NaOH}$ solution concentration $(\mathrm{mmol} / \mathrm{L})$; volume of $\mathrm{HCl}$ solution $(\mathrm{L})$ is notated as $\mathrm{V}_{\mathrm{HCl}} . \mathrm{V}_{\mathrm{NaOH}}$ is the volume of $\mathrm{NaOH}$ used in the titration of non-reacted acid's excess (L); weight of sample (g) is notated as $\mathrm{m}_{\text {sample }}$.

COD analysis was conducted using the titrimetric permanganate method, as $100 \mathrm{~mL}$ of the sample was treated with $1 \mathrm{~mL}$ of $6 \mathrm{~N} \mathrm{H}_{2} \mathrm{SO}_{4}$ and followed by $10 \mathrm{~mL}$ of $0.01 \mathrm{~N}$ $\mathrm{KMnO}_{4}$. The mixture in the flask was heated at boiling point and cooled down to room temperature for $10 \mathrm{~min}$, and further $10 \mathrm{~mL}$ of $0.01 \mathrm{~N}$ of $\mathrm{H}_{2} \mathrm{C}_{2} \mathrm{O}_{4} \cdot 2 \mathrm{H}_{2} \mathrm{O}$ was added to the flask. The mixture was titrated by $0.01 \mathrm{KMnO}_{4}$ until the color of solution become pink. The blank concentration using DI Water has to be measured as also titrated by $0.01 \mathrm{KMnO}_{4}$. The titration continued until the purple color on the mixture disappeared. The COD concentration was calculated by the following equation:

$$
\operatorname{COD}\left(\frac{\mathrm{mg}}{\mathrm{L}}\right)=\left[\left(\left((\mathrm{a}+\mathrm{b}) \times \mathrm{C} \mathrm{KMnO}_{4}\right)-\left((\mathrm{V} \times \mathrm{C}) \mathrm{H}_{2} \mathrm{C}_{2} \mathrm{O}_{4}\right)\right)\right] \times 8000
$$

where a is titration standardization volume of $\mathrm{KMnO}_{4}, \mathrm{~b}$ is titration sample volume of $\mathrm{KMnO}_{4}, \mathrm{C} \mathrm{KMnO}$ is solution concentration $(\mathrm{N}), \mathrm{V} \mathrm{H}_{2} \mathrm{C}_{2} \mathrm{O}_{4}(\mathrm{~L})$ and $\mathrm{H}_{2} \mathrm{C}_{2} \mathrm{O}_{4}$ are volume and concentration of $\mathrm{H}_{2} \mathrm{C}_{2} \mathrm{O}_{4}(\mathrm{~N})$, respectively.

TSS was analyzed using the Standard Test Method for Filterable and Nonfilterable Matter in Water. The sample was well-mixed, and then the measured volume of a water sample is filtered through a pre-weighed glass fiber filter. The filter was heated at $104 \pm 1^{\circ} \mathrm{C}$ until constant mass and then weighed. The TSS was calculated by the following equation:

$$
\operatorname{TSS}\left(\frac{\mathrm{mg}}{\mathrm{L}}\right)=\frac{(\mathrm{A}-\mathrm{B}) \times 100}{\mathrm{C}}
$$

where A is dry weight of residue and filter (mg), B is dry weight of filter (mg), and $\mathrm{C}$ is sample volume ( $\mathrm{L}$ ). The dye intensity was tested by UV-Vis spectroscopy (V-550JASCO, JASCO, Easto, MD, USA) which worked on wavelength maximum color adsorption on sample.

\section{Conclusions}

By incorporating amine magnetic with sugarcane bagasse to form a biocomposites, the material was successfully synthesized with high intensity of magnetic property. The utilization of sugarcane bagasse as biomass enhances the value added of waste material. The biocomposites showed excellent performances in $\mathrm{Pb}$ (II) ion adsorption, reduction of COD, TSS and dye in aqueous solution. In addition, the stable material tested for reusability was achieved with insignificant loss of performance. The synergic effects of amine magnetic sugarcane bagasse biocomposites on wastewater pollutant leads to this material having the potential to be developed and applied in waste water treatment. Therefore, the biocomposites are considered as one of the promising and attractive alternative materials for waste water cleaning and controlling environmental contamination. 
Author Contributions: Conceptualization, C.I., M.D.P. and I.F.N.; methodology, H.W. and Y.M.; validation, R.J. and I.F.N.; formal analysis, C.I., M.D.P., I.F.N. and Y.M.; investigation, H.W. and C.I.; writing—original draft preparation, I.F.N. and Y.M.; writing—review and editing, C.I., M.D.P. and H.W.; supervision, I.F.N. and M.D.P. All authors have read and agreed to the published version of the manuscript.

Funding: This research was funded by Ministry of Education, Culture, Research and Technology (Kemendikbudristek) Republic of Indonesia, through Graduate Research Project, grant number 113.1.09/UN8.2/PG/2020 and World Class Research, grant number 403/UN8.2/PG/2021.

Institutional Review Board Statement: Not applicable.

Informed Consent Statement: Not applicable.

Data Availability Statement: Not applicable.

Acknowledgments: The authors greatly thanks to Cheng-Kang Lee (National Taiwan University of Science and Technology, Taipei, Taiwan) for support the SQUID analysis.

Conflicts of Interest: The authors declare no conflict of interest.

Sample Availability: Samples of the compounds such as biocomposites, are available from the authors.

\section{References}

1. Pipíška, M.; Zarodňanská, S.; Horník, M.; Ďuriška, L.; Holub, M.; Šafařík, I. Magnetically Functionalized Moss Biomass as Biosorbent for Efficient $\mathrm{Co}^{2+}$ Ions and Thioflavin T Removal. Materials 2020, 13, 3619. [CrossRef] [PubMed]

2. FitzPatrick, M.; Champagne, P.; Cunningham, M.F.; Whitney, R.A. A biorefinery processing perspective: Treatment of lignocellulosic materials for the production of value-added products. Bioresour. Technol. 2010, 101, 8915-8922. [CrossRef] [PubMed]

3. Kumar, R.; Sharma, R.K.; Singh, A.P. Cellulose based grafted biosorbents-Journey from lignocellulose biomass to toxic metal ions sorption applications-A review. J. Mol. Liq. 2017, 232, 62-93. [CrossRef]

4. Balaji, A.; Karthikeyan, B.; Swaminathan, J.; Raj, C.S. Mechanical behavior of short bagasse fiber reinforced cardanol-formaldehyde composites. Fibers Polym. 2017, 18, 1193-1199. [CrossRef]

5. Candido, V.S.; da Silva, A.C.R.; Simonassi, N.T.; da Luz, F.S.; Monteiro, S.N. Toughness of polyester matrix composites reinforced with sugarcane bagasse fibers evaluated by Charpy impact tests. J. Mater. Res. Technol. 2017, 6, 334-338. [CrossRef]

6. Asrofi, M.; Sapuan, S.M.; Ilyas, R.A.; Ramesh, M. Characteristic of composite bioplastics from tapioca starch and sugarcane bagasse fiber: Effect of time duration of ultrasonication (Bath-Type). Mater. Today Proc. 2021, 46, 1626-1630. [CrossRef]

7. Toledo-Jaldin, H.P.; Sánchez-Mendieta, V.; Blanco-Flores, A.; López-Téllez, G.; Vilchis-Nestor, A.R.; Martín-Hernández, O. Low-cost sugarcane bagasse and peanut shell magnetic-composites applied in the removal of carbofuran and iprodione pesticides. Environ. Sci. Pollut. Res. 2020, 27, 7872-7885. [CrossRef]

8. Tanzifi, M.; Tavakkoli Yaraki, M.; Beiramzadeh, Z.; Heidarpoor Saremi, L.; Najafifard, M.; Moradi, H.; Mansouri, M.; Karami, M.; Bazgir, H. Carboxymethyl cellulose improved adsorption capacity of polypyrrole/CMC composite nanoparticles for removal of reactive dyes: Experimental optimization and DFT calculation. Chemosphere 2020, 255, 127052. [CrossRef]

9. Guo, Y.; Tan, C.; Sun, J.; Li, W.; Zhang, J.; Zhao, C. Porous activated carbons derived from waste sugarcane bagasse for $\mathrm{CO}_{2}$ adsorption. Chem. Eng. J. 2020, 381, 122736. [CrossRef]

10. Xavier, A.L.P.; Adarme, O.F.H.; Furtado, L.M.; Ferreira, G.M.D.; da Silva, L.H.M.; Gil, L.F.; Gurgel, L.V.A. Modeling adsorption of copper(II), cobalt(II) and nickel(II) metal ions from aqueous solution onto a new carboxylated sugarcane bagasse. Part II: Optimization of monocomponent fixed-bed column adsorption. J. Colloid Interface Sci. 2018, 516, 431-445. [CrossRef]

11. Cruz-Olivares, J.; Pérez-Alonso, C.; Barrera-Díaz, C.; Ureña-Nuñez, F.; Chaparro-Mercado, M.C.; Bilyeu, B. Modeling of lead (II) biosorption by residue of allspice in a fixed-bed column. Chem. Eng. J. 2013, 228, 21-27. [CrossRef]

12. Mahmood-ul-Hassan, M.; Suthar, V.; Rafique, E.; Ahmad, R.; Yasin, M. Kinetics of cadmium, chromium, and lead sorption onto chemically modified sugarcane bagasse and wheat straw. Environ. Monit. Assess. 2015, 187, 470. [CrossRef]

13. Vyavahare, G.D.; Gurav, R.G.; Jadhav, P.P.; Patil, R.R.; Aware, C.B.; Jadhav, J.P. Response surface methodology optimization for sorption of malachite green dye on sugarcane bagasse biochar and evaluating the residual dye for phyto and cytogenotoxicity. Chemosphere 2018, 194, 306-315. [CrossRef] [PubMed]

14. Javid, M.; Manoj, S. Impact of Textile Dyes on Human Health and Environment. In Impact of Textile Dyes on Public Health and the Environment; Khursheed Ahmad, W., Nirmala Kumari, J., Ajmal Rashid, B., Eds.; IGI Global: Hershey, PA, USA, 2020; pp. 162-169.

15. Wang, X.S.; Zhou, Y.; Jiang, Y.; Sun, C. The removal of basic dyes from aqueous solutions using agricultural by-products. J. Hazard. Mater. 2008, 157, 374-385. [CrossRef] [PubMed]

16. Wang, L.; Wang, Y.; Cui, L.; Gao, J.; Guo, Y.; Cheng, F. A sustainable approach for advanced removal of iron from CFA sulfuric acid leach liquor by solvent extraction with P507. Sep. Purif. Technol. 2020, 251, 117371. [CrossRef] 
17. Rocha de Freitas, G.; Adeodato Vieira, M.G.; Carlos da Silva, M.G. Characterization and biosorption of silver by biomass waste from the alginate industry. J. Clean. Prod. 2020, 271, 122588. [CrossRef]

18. Cai, Q.Q.; Wu, M.Y.; Hu, L.M.; Lee, B.C.Y.; Ong, S.L.; Wang, P.; Hu, J.Y. Organics removal and in-situ granule activated carbon regeneration in FBR-Fenton/GAC process for reverse osmosis concentrate treatment. Water Res. 2020, 183, 116119. [CrossRef]

19. Pehlivan, E.; Tran, H.T.; Ouédraogo, W.K.I.; Schmidt, C.; Zachmann, D.; Bahadir, M. Sugarcane bagasse treated with hydrous ferric oxide as a potential adsorbent for the removal of $\mathrm{As}(\mathrm{V})$ from aqueous solutions. Food Chem. 2013, 138, 133-138. [CrossRef]

20. Nata, I.F.; Wicakso, D.R.; Mirwan, A.; Irawan, C.; Ramadhani, D. Ursulla, Selective adsorption of Pb(II) ion on amine-rich functionalized rice husk magnetic nanoparticle biocomposites in aqueous solution. J. Environ. Chem. Eng. 2020, 8, 104339. [CrossRef]

21. Tan, Y.; Chen, M.; Hao, Y. High efficient removal of $\mathrm{Pb}(\mathrm{II})$ by amino-functionalized $\mathrm{Fe}_{3} \mathrm{O}_{4}$ magnetic nano-particles. Chem. Eng. J. 2012, 191, 104-111. [CrossRef]

22. Li, T.; Tong, Z.; Gao, B.; Li, Y.C.; Smyth, A.; Bayabil, H.K. Polyethyleneimine-modified biochar for enhanced phosphate adsorption. Environ. Sci. Pollut. Res. 2020, 27, 7420-7429. [CrossRef]

23. Martín-Lara, M.Á.; Rico, I.L.R.; Vicente, I.D.L.C.A.; García, G.B.; de Hoces, M.C. Modification of the sorptive characteristics of sugarcane bagasse for removing lead from aqueous solutions. Desalination 2010, 256, 58-63. [CrossRef]

24. Nata, I.F.; Mirwan, A.; Wicakso, D.R.; Irawan, C.; Isnaini, M.D.; Fitriani, R. Adsorption of Fe ${ }^{3+}$ ion from Aqueous Solution onto Rice Husk Biocomposite Magnetic Nanoparticle. IOP Conf. Ser. Earth Environ. Sci. 2020, 506, 012006. [CrossRef]

25. Rodrigues, E.F.; Maia, T.F.; Mulinari, D.R. Tensile strength of polyester resin reinforced sugarcane bagasse fibers modified by estherification. Procedia Eng. 2011, 10, 2348-2352. [CrossRef]

26. Pi, X.; Sun, F.; Gao, J.; Qu, Z.; Wang, A.; Qie, Z.; Wang, L.; Liu, H. A new insight into the $\mathrm{SO}_{2}$ adsorption behavior of oxidized carbon materials using model adsorbents and DFT calculations. Phys. Chem. Chem. Phys. 2019, 21, 9181-9188. [CrossRef]

27. Bi, F.; Zhang, X.; Xiang, S.; Wang, Y. Effect of Pd loading on $\mathrm{ZrO}_{2}$ support resulting from pyrolysis of UiO-66: Application to CO oxidation. J. Colloid Interface Sci. 2020, 573, 11-20. [CrossRef] [PubMed]

28. Mohit, H.; Selvan, V. Thermo-mechanical properties of sodium chloride and alkali-treated sugarcane bagasse fibre. Indian J. Fibre Text. Res. 2019, 44, 286-293.

29. Zhang, X.; Kan, X.; Wang, M.; Rao, R.; Qian, N.; Zheng, G.; Ma, Y. Mechanism of enhanced magnetization in $\mathrm{CoFe}_{2} \mathrm{O}_{4} / \mathrm{La}_{0.7} \mathrm{Sr}_{0.3}$ $\mathrm{MnO}_{3}$ composites with different mass ratios. Ceram. Int. 2020, 46 Pt A, 14847-14856. [CrossRef]

30. Yam, R.C.M.; Mak, D.M.T. A cleaner production of rice husk-blended polypropylene eco-composite by gas-assisted injection moulding. J. Clean. Prod. 2014, 67, 277-284. [CrossRef]

31. Xiao, R.; Yang, W.; Cong, X.; Dong, K.; Xu, J.; Wang, D.; Yang, X. Thermogravimetric analysis and reaction kinetics of lignocellulosic biomass pyrolysis. Energy 2020, 201, 117537. [CrossRef]

32. Lagrergen, S. Zur Theorie Der Sogenannten Adsorption Gelöster Stoffe Kungliga Svenska Vetenskapsakademiens. Handlingar 1898, 24, 1-39.

33. Ho, Y.-S.; McKay, G. Pseudo-second order model for sorption processes. Process Biochem. 1999, 34, 451-465. [CrossRef]

34. Liu, W.; Zhao, C.; Wang, S.; Niu, L.; Wang, Y.; Liang, S.; Cui, Z. Adsorption of cadmium ions from aqueous solutions using nano-montmorillonite: Kinetics, isotherm and mechanism evaluations. Res. Chem. Intermed. 2018, 44, 1441-1458. [CrossRef]

35. Chu, Y.; Khan, M.A.; Wang, F.; Xia, M.; Lei, W.; Zhu, S. Kinetics and equilibrium isotherms of adsorption of Pb(II) and Cu(II) onto raw and arginine-modified montmorillonite. Adv. Powder Technol. 2019, 30, 1067-1078. [CrossRef]

36. Gómez-Pastora, J.; Bringas, E.; Ortiz, I. Recent progress and future challenges on the use of high performance magnetic nanoadsorbents in environmental applications. Chem. Eng. J. 2014, 256, 187-204. [CrossRef]

37. Xiong, C.; Wang, S.; Sun, W.; Li, Y. Selective adsorption of $\mathrm{Pb}$ (II) from aqueous solution using nanosilica functionalized with diethanolamine: Equilibrium, kinetic and thermodynamic. Microchem. J. 2019, 146, 270-278. [CrossRef]

38. Hamza, I.A.; Martincigh, B.S.; Ngila, J.C.; Nyamori, V.O. Adsorption studies of aqueous Pb(II) onto a sugarcane bagasse/multiwalled carbon nanotube composite. Phys. Chem. Earth Parts A/B/C 2013, 66, 157-166. [CrossRef]

39. Lucinaldo, S.; Luciano, C.; Fransisco, J.; Mateus, S.; Josy, A.; Roosevelt, D.; Edson, C. Sorption of the Anionic Rective Red RB Dye in Cellulose: Assesment of Kinetic, Thermodynamic, and Equilibrium. Open Chem. 2015, 13, 801-812.

40. El-Gawad, S.A.; El-Aziz, H.M. Effective removal of chemical oxygen demand and phosphates from aqueous medium using entrapped activated carbon in alginate. MOJ Biol. Med. 2018, 3, 227-236. [CrossRef]

41. Pan, Y.; Zhu, Y.; Xu, Z.; Lu, R.; Zhang, Z.; Liang, M.; Liu, H. Adsorption Removal of COD from Wastewater by the Activated Carbons Prepared from Sugarcane Bagasse. In Proceedings of the 5th International Conference on Bioinformatics and Biomedical Engineering (iCBBE 2011), Wuhan, China, 10-12 May 2011.

42. Sivashankar, R.; Sathya, A.; Sivasubramanian, V. Synthesis of magnetic biocomposite for efficient adsorption of azo dye from aqueous solution. Ecotoxicol. Environ. Saf. 2015, 121, 149-153. [CrossRef]

43. Alsuhybani, M.; Alshahrani, A.; Algamdi, M.; Al-Kahtani, A.A.; Alqadami, A.A. Highly efficient removal of Pb(II) from aqueous systems using a new nanocomposite: Adsorption, isotherm, kinetic and mechanism studies. J. Mol. Liq. 2020, $301,112393$. [CrossRef]

44. Tan, Y.; Wang, K.; Yan, Q.; Zhang, S.; Li, J.; Ji, Y. Synthesis of Amino-Functionalized Waste Wood Flour Adsorbent for HighCapacity $\mathrm{Pb}(\mathrm{II})$ Adsorption. ACS Omega 2019, 4, 10475-10484. [CrossRef] 
45. Jafarnejad, M.; Asli, M.D.; Taromi, F.A.; Manoochehri, M. Synthesis of multi-functionalized $\mathrm{Fe}_{3} \mathrm{O}_{4}-\mathrm{NH}_{2}-\mathrm{SH}_{\mathrm{H}}$ nanofiber based on chitosan for single and simultaneous adsorption of $\mathrm{Pb}(\mathrm{II})$ and $\mathrm{Ni}(\mathrm{II})$ from aqueous system. Int. J. Biol. Macromol. 2020, 148, 201-217. [CrossRef]

46. Pi-Boleda, B.; Bouzas, M.; Gaztelumendi, N.; Illa, O.; Nogués, C.; Branchadell, V.; Pons, R.; Ortuño, R.M. Chiral pH-sensitive cyclobutane $\beta$-amino acid-based cationic amphiphiles: Possible candidates for use in gene therapy. J. Mol. Liq. 2020, $297,111856$. [CrossRef] 